\title{
DOI: 10.31548/hspedagog2021.03.043
}

УДК 159.9: 316.36

CHOICE OF BEHAVIOR STRATEGIES FOR SPOUSES IN RESOLVING FAMILY CONFLICTS

OLIINYK O.O., candidate of psychological sciences, PhD (Psychology), associate professor, associate professor of department of the Psychology, National University of Life and Environmental Sciences of Ukraine

E-mail: okleons777@gmail.com

ORCID ID 0000-0002-3255-9170

\begin{abstract}
Family conflicts contribute to the reassessment of the system of values, the transformation of social relations and interpersonal relations, the development of the family system, are a source of change for each of its participants. The leading role in the construction of the family system and good relations in it belongs to the marital subsystem, which determines the development of relations in other family subsystems. The propensity of each spouse to conflict behavior, as well as the choice of appropriate behavioral strategies determines the success of resolving family conflicts. Objective. The research is related to the analysis of the essence of the "family conflict" concept and the characteristics of behavioral strategies in conflict; experimental definition and analysis of the main behavior strategies of spouses in resolving family conflicts. Methods. To solve the research problem we used such theoretical research methods as: analysis of scientific psychological literature, generalization, systematization of scientific information; the following empirical research methods were used: conversation, observation, psychodiagnostic method "Diagnosis of a person's propensity to conflict behavior" by K. Thomas adapted by N. V. Hryshyna; processing and quantitative and qualitative interpretation of results. The study involved 16 married couples (husband and wife) with different marital experiences in the number of 32 people aged 26 to 48 years (Kyiv). All the couples have children aged 2 to 21 years. The results of the empirical study of the peculiarities of the behavior strategies choice for spouses in resolving family conflicts showed that the predominant strategies are: "Compromise", which was found in $28.12 \%$ of the total number of respondents and $37.5 \%$ of women in particular; "Rivalry", which was found in $25 \%$ of the total number of respondents and $31.25 \%$ of men in particular; respondents are the least likely to choose the "Avoidance" strategy - $9.38 \%$ of the total number of respondents, $6.25 \%$ of women and $12.5 \%$ of men. We see the prospects for further development in the study of family values and role attitudes of a married couple and their relationship with the effective resolution of conflicts in the family.
\end{abstract}

Keywords: family, spouses, marriage partners, family conflicts, propensity to conflict, behavior strategies in conflict.

Urgency of the research. The dynamics of human life, social contacts, information overload, multi-functionality leads to an increasing number of conflict situations in various spheres of life. Conflicts contribute to the reassessment of the system of values, the transformation of social relations and interpersonal relations, social system development, are a source of change for each of its participants. After all, a constructive solution to various types and kinds of conflicts contributes to the development of social systems. The family is an important social system in which personality is formed and developed throughout life. Its functioning is impossible without the collision of oppositely directed ideas, views, and motives of all family members. Spouses, parents and children and other relatives are the subjects of family conflicts. The leading role in the construction of the family system and good relations in it 
belongs to the marital subsystem, which determines the development of relations in other family subsystems. Important factors in the constructive and destructive resolution of family conflicts are the propensity of each spouse to conflict behavior, as well as the choice of appropriate behavior strategies, which necessitates research on this problem.

Analysis of recent research and publications. Theoretical analysis of the scientific literature on the problem of conflicts and peculiarities of behavior in them allows determining the concept of conflict, style, strategy of behavior in conflict and conflict factors. Thus, the researchers have analyzed the essence of family conflict, the causes of its occurrence, features of prevention, settlement and resolution [3]. It is noted that conflicts are an integral part of human life, which "chooses different behavior strategies that lead to both positive and negative consequences" [ 1 , p. 208].

In modern research, due attention is paid to the study of types of behavior during conflict, strategies of psychological protection in conflicts, styles of interpersonal relationships, manifestations of frustration, aggression and rigidity of people with different levels of anxiety [7].

Factors of family conflicts include: transitional periods of the family cycle, individual characteristics of family members, features of communication between spouses; gender manifestations and age features of spouses [8, p. 60-61]. Also the scientists consider the social identity of the individual to be an important factor in choosing a style of behavior in conflict [5]. Thus, theoretical analysis of the scientific literature, empirical studies of the choice of strategies for behavior of spouses in resolving family conflicts will contribute to the conscious choice of optimal ways of responding to conflicts, understanding their consequences and prevention of destructive forms of conflict.
Research objective. To analyze the essence of the concepts: "family conflict", "behavior strategies in conflict"; to experimentally identify and analyze the features of the choice of spouses' behavioral strategies in resolving family conflicts.

Materials and methods of the research. To solve the research problem we used such theoretical research methods as: analysis of scientific psychological literature, generalization, systematization of scientific information; the following empirical research methods were used: conversation, observation, psychodiagnostic method "Diagnosis of a person's propensity to conflict behavior", adapted by N.V. Hryshyna; processing and quantitative and qualitative interpretation of results.

Presentation of basic material of the research. The term "conflict" comes from the Latin "conflictus", which means "collision". This concept is more broadly characterized as a state of open, often protracted struggle; state of disharmony in relations between people, ideas, interests; mental struggle based on the inner opposite desires of man; emotional tension etc. [5, p. 20].

Among the main features of the conflict are the following: a collision, which is characterized as bipolarity and means interconnectedness and mutual opposition at the same time; activity aimed at overcoming contradictions; the presence of the subject or subjects as carriers of the conflict [2, p. 15].

Behavior style in a conflict situation is crucial for further development and completion of the conflict. In particular, K. Thomas determines the following conditions for productive termination of conflict interaction [7, p. 161]:

1) adequate assessment of the measure through which the individual seeks to satisfy his/her own interests and the interests of the other party;

2) awareness of the feasibility of the chosen behavior in accordance with the specific situation; 
3) taking into account the strength of the opponent, the power he/she has;

4) more correct definition of the source of conflict;

5) objective establishment of the nature of the relationship with the other party;

6) taking into account own personal characteristics and characteristics of the opponent.

It is worth noting that conflict is a means of revitalizing the social life of the family. It supports social activity, helps prevent stagnation and is a source of development and innovation. In functional families, conflicts are manifested, developed and resolved in a positive relationship. Destructive conflicts, which negatively affect the production of common views of spouses, lead to disorganization of interaction and communication [8, p. 61].

K. Thomas identifies five styles of behavior in conflict:

- competition or rivalry characterizes the desire to satisfy their own interests in the prejudice of others;

- cooperation - the situation participants come to an alternative that fully satisfies the interests of both parties; the participants of the conflict have common goals, ways to solve the problem;

- compromise - partial satisfaction of the needs and interests of each party through mutual concessions;

- adaptation - the refusal to satisfy their own interests for the sake of another; lack of desire to defend their own views and ideas in order to smooth the psychological atmosphere;

- avoidance - lack of desire for cooperation and lack of tendency to achieve their own goals. A person avoids conflict in any way, tries in any situation to pretend that nothing happened; he/she often says that he/she considers himself/herself non-conflict. As a result, neither own interests nor the interests of the opponent are satisfied [1, p. 47-57; 8, p. $61 ; 6$, p. 471$]$.
Thus, family

well-being, harmonious development of the family in different cycles of its existence, satisfaction of the spouses with marriage and each other depend on the correct choice of behavior strategy in the conflict. In order to clarify the peculiarities of the behavior strategies choice in family conflict between spouses, we conducted an empirical study in which we applied the psychodiagnostic method "Diagnosis of a person's propensity to conflict behavior" by K. Thomas adapted by N.V. Hryshyna, which purpose is to determine the predominant behavior of each spouse in conflict situations. This psychodiagnostic technique contains 30 questions, each of which has 2 answer options. The respondents should choose in each question only one of the proposed options that best suits their views.

This technique is used to diagnose the dominant behavior strategies in the conflict (methods of conflict management) on the following scales: 1) competition; 2) cooperation; 3 3) compromise; 4) adaptation; 5) avoidance [6, p. 470475].

The empirical study was conducted during March-May 2021. The study involved 16 married couples (husband and wife) with different marital experiences in the number of 32 people aged 26 to 48 years (Kyiv). All the couples have children aged 2 to 21 years. The respondents belong to different age groups and have different experiences of family life, which makes it possible to diagnose a range of qualitative and quantitative characteristics regarding the choice of behavior strategies of each spouse in resolving family conflicts.

Research results and their discussion. According to the results of the method "Diagnosis of a person's propensity to conflict behavior" by K. Thomas adapted by N. V. Hryshyna, the peculiarities of the spouses' choice of dominant behavioral strategies in resolving family conflicts were analyzed. Quantitative indices of the selected behavior strategies distribution in the 
conflict of each spouse are given in

Table. 1.

Table 1

Distribution of the chosen behavior strategies in the conflict of each spouse according to the method Diagnosis of a person's propensity to conflict behavior" by K. Thomas adapted by N. V. Hryshyna

\begin{tabular}{|c|c|c|c|c|}
\hline \multirow{2}{*}{$\begin{array}{c}\text { Behavioral } \\
\text { strategies in } \\
\text { conflict } \\
\text { resolution }\end{array}$} & \multicolumn{4}{|c|}{ Number of respondents } \\
\cline { 2 - 5 } & Men (\%) & $\begin{array}{c}\text { Women } \\
(\%)\end{array}$ & $\begin{array}{c}\text { General number of } \\
\text { respondents (\%) }\end{array}$ & $\begin{array}{c}\text { Married } \\
\text { couples } \\
(\%)\end{array}$ \\
\hline Cooperation & 12,5 & 25 & 18,75 & 12,5 \\
\hline Rivalry & 31,25 & 18,75 & 25 & 12,5 \\
\hline Compromise & 18,75 & 37,5 & 28,12 & 6,25 \\
\hline Avoidance & 12,5 & 6,25 & 9,38 & - \\
\hline Adaptation & 25 & 12,5 & 18,75 & - \\
\hline
\end{tabular}

The results given in Table 1 show that the choice of behavior strategies in resolving family conflicts in the studied couples is uneven:

1) the most common strategy for resolving conflict situations is the "Compromise" strategy was found in the total number of respondents $(28.12 \%)$ and in women in particular (37.5\%);

2) the "Rivalry" strategy is also predominant in this sample, which was found in $25 \%$ of the total number of respondents and in men in particular $(31.25 \%)$;

3) the choice of strategy "Cooperation" in resolving family conflicts is preferred by $18.75 \%$ of the total number of respondents and $25 \%$ of women in particular;

4) $18.75 \%$ of the total number of respondents and $25 \%$ of men in particular are inclined to use the "Adaptation" strategy;

5) the least respondents choose the strategy of "Avoidance" $-9.38 \%$ of the total number of respondents, $6.25 \%$ of women and $12.5 \%$ of men.
The results show that women mostly choose the strategies of "Cooperation" (37.5\%) and "Compromise" (25\%), while men are more likely to choose strategies of "Rivalry" (31.25\%) and "Adaptation" (25 $\%)$.

It should be noted that full compliance with the use of one behavior strategy during a conflict situation was found in $31.25 \%$ of married couples where both husband and wife use the same behavior strategy during a conflict situation, namely:

1) the strategy of "Rivalry" is chosen by $12.5 \%$ of married couples. This is determined by the desire to meet their own needs and interests at any cost, regardless of the goals and interests of the spouse;

2) the strategy of "Cooperation" is also chosen by $12.5 \%$ of married couples, which is characterized by behavior aimed at satisfying the interests of both parties to the conflict;

3 ) the strategy of "Compromise" is chosen by $6.25 \%$ of married couples/ It 
involves the desire to defend their own interests and make mutual concessions in order to satisfy them.

Conclusions and directions for future research. Analysis of behavior strategies in family conflict has shown that when choosing a particular strategy, marriage partners must take into account their own resources, the specific situation and its likely consequences. The best option for spouses to choose a behavior strategy in family conflict is the situation based on the analysis of all components of the conflict: causes, resources, subject and object of the conflict, conflict conditions, peculiarities of their own perception of the conflict and its significance for each participant. Experiments have shown that the most typical strategies for women are "Cooperation" and "Compromise", while men are more likely to choose strategies of "Rivalry" and "Adaptation". This indicates the tendency of women to make alternative decisions that can meet the interests of both parties, as well as to partially meet their own needs through mutual concessions. Men show the dominance of ambivalent strategies, which is characterized by the desire to satisfy their own interests, regardless of the goals and interests of the spouse, as well as the refusal to satisfy their own interests for the sake of smoothing the psychological atmosphere.

The prospects for further research are seen in the study of family values and role attitudes in a married couple and their relationship with the effective resolution of conflicts in the family.

\section{Список використаних джерел}

1. Барабаш О. Стратегії поведінки в конфліктній ситуації. Теорія держави і права. 2017. №3. С. 208-212.

2. Гришина Н.В. Психология конфрликта. СПб. : Питер, 2000. 464 с.

3. Кругла Т. О. Сімейний конфрлікт: причини виникнення, попередження, врегулювання. Медсестринство. 2017. № 4. С. 71-74.
4. Ложкин Г. В., Повякель Н. И. Практическая психология конфликта : учеб. пособие. Киев : МАУП, 2002. 225 c.

5. Пилат Н.I. Соціальна ідентичність особистості як чинник вибору стилю поведінки в конфрлікті : дис.... канд. психол. наук : спец. 19.00.05; Ін-т психології ім. Г.С. Костюка АПН України. К.,2004. 177 с.

6. Райгородский Д.Я. Практическая психодиагностика. Методики и тесты: Учеб. пос. Самара: Издательский дом «БАХРАХ-М», 2002. 672 c.

7. Романенко О. В., Лукашенко М. Ю. Особливості поведінки в конфрліктних ситуаціях осіб із різним рівнем тривожності. Юридична психологія. 2017. № 2 (21). C. 21-29.

8. Хомовиченко О.В., Власенко І.А. Психологічні особливості поведінки в сімейному конфлікті подружжя середнього віку. Педагогічна освіта: теорія і практика. Психологія. Педагогіка: Збірник наукових праць. 2019. № 31. C. 59-65.

\section{References}

1. Barabash O. (2017). Stratehii povedinky $v$ konfliktnii sytuatsii [Strategies of behavior in a conflict situation]. Teoriia derzhavy i prava. №3. P. 208-212 (in Ukrainian).

2. Grishina N.V. (2000). Psihologiya konflikta [The psychology of conflict]. SPb. : Piter (in Russian).

3. Kruhla T. O. (2017). Simeinyi konflikt: prychyny vynyknennia, poperedzhennia, vrehuliuvannia [Family conflict: causes, prevention, settlement]. Medsestrynstvo. № 4. P. 71-74 (in Ukrainian).

4. Lozhkin G. V., Povyakel N. I. (2002). Prakticheskaya psihologiya konflikta : ucheb. posobie. [Practical psychology of conflict: textbook. allowance]. Kiev : MAUP (in Ukrainian).

5. Pylat N.I. (2004). Social identity of the individual as a factor in choosing a style of behavior in conflict. 
Candidate's thesis. K.: Institute of Psychology. G.S. Kostyuk Academy of Pedagogical Sciences of Ukraine (in Ukrainian).

6. Raygorodskiy D.Ya. (2002). Prakticheskaya psihodiagnostika. Metodiki i testyi: Ucheb. pos. [Practical psychodiagnostics. Techniques and tests: Textbook. pos.]. Samara: Izdatelskiy dom «BAHRAH-M» (in Russian).

7. Romanenko O. V., Lukashenko M. Yu. (2017). Osoblyvosti povedinky $v$ konfliktnykh sytuatsiiakh osib iz riznym rivnem tryvozhnosti [Features of behavior in conflict situations of people with different levels of anxiety]. Yurydychna psykholohiia. № 2 (21). P. 21-29. (in Ukrainian).

8. Khomovychenko O.V., Vlasenko I.A. (2019). Psykholohichni osoblyvosti povedinky $v$ simeinomu konflikti podruzhzhia serednoho viku. [Psychological features of behavior in family conflict of middle-aged couples]. Pedahohichna osvita: teoriia i praktyka. Psykholohiia. Pedahohika: Zbirnyk naukovykh prats. № 31. P. 59-65. (in Ukrainian).

\section{ВИБІР СТРАТЕГІЙ ПОВЕДІНКИ ПОДРУЖЖЯМ У ВИРІШЕННІ СІМЕЙНИХ КОНФЛІКТІВ \\ Олійник О. 0.}

Анотація. Сімейні конфрлікти сприяють переоцінці системи цінностей, трансорормації соціальних стосунків та міжособистісних відносин, розвитку сімейної системи, виступають джерелом змін кожного з ї̈ учасників. Провідна роль у побудові сімейної системи, конструктивних відносин у ній належить подружній підсистемі, яка визначає розвиток стосунків у інших сімейних підсистемах. Схильність кожного з подружжя до конфлліктної поведінки, а також вибір ними відповідних стратегій поведінки визначають успішність вирішення сімейних конфоліктів. Мета. Дослідження пов'язане з аналізом сутності поняття «сімейний конфлікт» та характеристикою стратегій поведінки в конфрлікті; експериментальним визначенням та аналізом основних стратегій поведінки подружжя у вирішенні сімейних конфрліктів. Методи. Для розв'язання дослідницької проблеми нами було використано теоретичні методи дослідження: аналіз наукової психологічної літератури, узагальнення, систематизація наукової інформації; застосовувались емпіричні методи дослідження: бесіда, спостереження, психодіагностична методика "Діагностика схильності особистості до конфліктної поведінки» К. Томаса в адаптації Н. В. Гришиної; обробки та кількісної $і$ якісної інтерпретації результатів. У дослідженні брали участь 16 сімейних пар (чоловік і дружина) з різним досвідом подружнього життя у кількості 32 осіб віком від 26 до 48 років (м. Київ). Всі пари мають дітей віком від 2 до 21 років. Результати емпіричного дослідження особливостей вибору стратегій поведінки подружжям у вирішенні сімейних конфрліктів показав, що переважаючими стратегіями $\epsilon$ : «компроміс», яка виявлена у 28,12\% загальної кількості респондентів та у 37,5\% жінок зокрема; «суперництво», яка виявлена у $25 \%$ загальної кількості респондентів та у 31,25 \% чоловіків зокрема; найменше респонденти обирають стратегію «уникнення» - 9,38 \% загальної кількості респондентів, 6,25 \% жінок та 12,5 \% чоловіків. Перспективи подальших розробок вбачаємо в дослідженні сімейних цінностей і рольових установок у подружній парі та їх взаємозв'язку із ефективним вирішенням конфрліктів у сім'ї.

Ключові слова: сім'я, подружжя, шлюбні партнери, сімейні конфрлікти, схильність до конфрлікту, стратеаї поведінки в конфрлікті. 


\title{
DOI: $10.31548 / \mathrm{hspedagog} 2021.03 .049$
}

COMMUNICATIVE ATTITUDES AS A FACTOR OF SUBJECTIVE WELL-BEING OF THE INDIVIDUAL

OMELCHENKO L. M. , PhD, associate professor National University of Life and Environmental Sciences of Ukraine

E-mail: omelchenko2006@nubip.edu.ua

\begin{abstract}
The article is devoted to the analysis of the influence of communicative attitudes on the subjective well-being of the individual. As a result of the theoretical analysis, it is revealed that communicative attitudes are a kind of social, they are manifested in the process of communicative interaction when determining the subjectthematic interests of the partner, the attitude to the form of communication, the inclusion of partners in the system of communicative interaction. They manifest themselves in the attitude of the subject of communication to himself, to other participants in communication, to the communication process itself. Negative communication attitudes have an adverse effect on the process of interaction between people, the suppression of negative attitudes is difficult to mask, which leads to the appearance of problems in interpersonal relationships. Communicative attitudes affect the formation of subjective well-being of the individual. Negative communication experience determines the appearance of difficulties in the emotional, cognitive, and behavioral spheres of the individual, which negatively affect various levels of subjective well-being of a person.
\end{abstract}

Keywords: social attitudes, communication attitudes, positive communication attitudes, negative communication attitudes, subjective well-being.

Introduction. The life of a modern person is marked by numerous crises: overpopulation, global warming, aggravation of social and economic contradictions, the covid-19 pandemic. That is why one of the most urgent problems of humanity is the level of its mental health. According to the WHO, mental health is not just the absence of mental illness This is a state of well-being of a person, in which he can realize his own potential, cope with life's stresses, work productively and fruitfully, and contribute to the life of his community [4]. Well-being determines the level of social adaptability of an individual, his ability to analyze and overcome a situation of uncertainty. It is, to a certain extent, a subjective assessment of a person's own life, carried out on the basis of unconscious and conscious attitudes. That is why the study of the influence of communicative attitudes on a person's experience of his subjective well-being is of particular importance.

\section{Analysis of recent researches} and publications. Communicative attitudes of the individual have become the subject of scientific research by both domestic and foreign scientists. Thus, in the Western scientific paradigm, this concept is explained in the research of W. Thomas, F. Zanetsky, R. Woodworths, L. Lange, G. Muller, T. Schumann, G. Kelly, N. Miller, M. Sheriff, T. Shibutani. In Russian science, this concept was studied by G. Andreeva, O. Bodalev, L. Vygotsky, Sh. Nadirashvili, V. Boyko, S. Fedotov, N. Belska. These scientists justified the essence of the concepts of «social attitude», "communicative attitude», found out its daily characteristics, significance in the system of social interaction and communication. However, further research requires the problem of interdependence of the communicative attitude and subjective well-being of a person.

Purpose. The purpose of the article: to analyze the influence of a person's communicative attitudes on their subjective well-being.

Methods. To write the article, the following methods were used: theoretical - analysis, comparison, synthesis, 